\title{
Improving School through the Voice of the Students. Notes about an Experience Carried out in Cantabria (Spain)
}

\author{
Marta García Lastra \\ University of Cantabria, Spain
}

\begin{abstract}
By means of this paper we summarize the work carried out during three years with a group of students from the Spanish Compulsory Secondary Education with the aim that they may address their demands and needs to the school management team so as to improve their school experience. The approach of the work stems from two clear concepts: on the one hand, the student's point of view, their voice, as a key piece in the educational processes and on the other hand, the need to count on the centres themselves, through their particular dynamics, to set in motion school improvement actions geared to the creation of inclusive schools and where all students are recognized alike. In the paper we will indicate the methodology used in the project, the phases followed and the evaluation carried out by pupils, tutor and researchers.
\end{abstract}

\section{Introduction}

This paper summarizes the experience of three years' work in a secondary education school within a broader research study being carried out at the University of Cantabria (UC). The project we are running belongs to the national call for projects financed by the Spanish Ministry of Science and Technology (Dir. Teresa Susinos, I+D+i, EDU200806511-C02-02/EDUC) and whose aim is to promote, in different schools, improvements that have been designed and developed based on student voice. We thus seek for student participation in schools to be a mechanism of change and institutional improvement in order to accomplishing more inclusive and democratic schools.

As a result of interest in the implementation of programs that can increase this voice and, consequently, generate school improvement processes that conclude in more inclusive schools, for the last years we have been working in the project "Analysis of the processes of inclusion / exclusion of education in compulsory education.
Development of local projects for change and school improvement.".

Our work seeks to provoke debate about the model of inclusive education, which has been conceived as being a basic principle in current education policies, with the student voice movement, stressing the indissoluble relationship between voice (of any traditionally silenced group) and inclusion [1; $2 ; 3 ; 4]$. This way, our work, as we have presented it at other congresses and in other publications [5; 6; 7], seeks to broaden the reach of student voice through its participation in the school life of which it is part, chiefly in those areas where it has hardly been heard throughout the years. We start off from the idea of the blinkered vision of schools when it comes to defining areas of decision and student participation, and as a consequence, the need and requirement to broaden this.

The project has been carried out in various centres with different education levels from the community of Cantabria (Spain), showing how these types of practices can be run at all levels of education, from Childhood education to Secondary, with the due appropriate adaptation. In this sense, we can talk about a multilevel project where, despite the general principles that rule research, we have carried out a process of adapting the said proposals to the reality of each centre and/or level. Thus, the research team agreed at the start of the work to a sequence of five fundamental stages or steps that we will explain fully below. Naturally, we must understand that the peculiarity of each education level, the demands of the tutors or teachers involved, as well as the singularity of the pupils, will provide the backbone to the setting in motion of the project in each of the different centres.

In this article, we present the work carried out in the Secondary Education level in a grant-assisted school in Santander over the last three years. The school is located on the outskirts of Santander (capital of the region) where more than 300 pupils study from Infants to Secondary. A large number of the students come from a low social, economic and 
cultural background, a situation that is present in the daily work of the centre. There are also a high number of romani children due to the presence of a Roma settlement in the catchment area that has gone back some time. Against this backcloth, the school has become a reference point in the neighborhood in which it is located, with strong involvement with the community. This fact is reflected in terms of: the offer of services for the adult, the attention given to the needs of the most underprivileged groups or the participation in any action that may represent an improvement in the quality of life of the area.

Our project was carried out with a group who started participating in our project when the pupils were in year 3 of Secondary and continued until they left school in year $4^{1}$. The group comprised 23 students including those in the group termed "diversification", that is to say, pupils who for differing reasons are following a different curriculum in most subjects from the rest of their schoolmates. Participation of all students from the group in the whole process, including, in a special way, those showing most passiveness, lack of interest or worst academic performance, has been one of the core objectives of the experience we present.

We now move on to describing the work carried out throughout these years. To do this we evaluate the different phases designed in the project, placing special emphasis on the last two years, referring to the work carried out with the students which we considered as the "keystone" of our work. The last phase, aimed at evaluating the work carried out in the centre and the project itself as a whole, offered us the opportunity to offer some reflections that, once the project had finished, we posed to the research team, centre tutor and the pupils themselves.

\section{What have we done over these years?}

Our work can be considered as a "collaborative research project” following Ainscow's terms [8], who defined this kind of cooperation as a project run by the teachers of the school centre in collaboration with the research team, this case from the university, in such a way that both parties become coresearchers of the whole process. We feel that throughout the years of this joint work we are in a good position to talk about a mutual learning process between those persons involved in it: the researchers from the UC, the centre tutor, the students, the

\footnotetext{
${ }^{1}$ We would like to point out that in Spain Compulsory Secondary Education (ESO) currently comprises 4 years : $1^{\text {st }}$ and $2^{\text {nd }}$ (First ESO cycle) and $3^{\text {rd }}$ and $4^{\text {th }}$ (Second ESO cycle)
}

management and the schools as a whole. We would like to point out that the process we will describe below has been a gradual process in which not only did we increase the intensity of the work carried out but also the enthusiasm of the persons involved, and chiefly the pupils who have seen " we are capable of proposing ideas and that people listen to us”.

As we mentioned above, the project was set out in five stages, planned and negotiated with the research team from the outset. A summary of the stages, objectives and tasks to be carried out in each of the stages is detailed in the following table (Table 1):

Table 1. Stages, objectives and tasks

\begin{tabular}{|c|c|c|}
\hline Stages & Objectives & Tasks \\
\hline $\begin{array}{l}\text { Choice of } \\
\text { centres and } \\
\text { negotiation of } \\
\text { the research } \\
\text { process }\end{array}$ & $\begin{array}{l}\text { Choosing } \\
\text { schools to } \\
\text { participate in } \\
\text { the Project. } \\
\text { Advertising } \\
\text { the aims and } \\
\text { implications } \\
\text { of the Project }\end{array}$ & $\begin{array}{l}\text { Entry in the } \\
\text { centre } \\
\text { Presentation of } \\
\text { the Project to the } \\
\text { centre } \\
\text { management team } \\
\text { Contact with the } \\
\text { tutor }\end{array}$ \\
\hline $\begin{array}{l}\text { Identifying } \\
\text { needs }\end{array}$ & $\begin{array}{l}\text { Knowing the } \\
\text { opinion of the } \\
\text { tutor as to the } \\
\text { dynamics of } \\
\text { the work and } \\
\text { pupil } \\
\text { participation }\end{array}$ & $\begin{array}{l}\text { Carrying out } \\
\text { interviews with } \\
\text { the head teacher } \\
\text { and tutor } \\
\text { Observations in } \\
\text { the classroom } \\
\text { Analysis } \\
\text { interviews } \\
\text { (transcriptions) } \\
\text { and observations } \\
\text { (table) }\end{array}$ \\
\hline $\begin{array}{l}\text { Delivery of } \\
\text { information }\end{array}$ & $\begin{array}{l}\text { Designing } \\
\text { "topics" in } \\
\text { terms of the } \\
\text { information } \\
\text { compiled } \\
\text { Compiling the } \\
\text { researcher's }\end{array}$ & $\begin{array}{l}\text { Handing back } \\
\text { transcripts from } \\
\text { interviews } \\
\text { Meetings } \\
\text { (dialogue) with } \\
\text { the tutor } \\
\text { Preparation of the }\end{array}$ \\
\hline
\end{tabular}




\begin{tabular}{|c|c|c|}
\hline & $\begin{array}{l}\text { conclusions } \\
\text { with the } \\
\text { opinions of } \\
\text { the tutor }\end{array}$ & $\begin{array}{l}\text { activity to be } \\
\text { carried out with } \\
\text { the students }\end{array}$ \\
\hline $\begin{array}{l}\text { Work with } \\
\text { students }\end{array}$ & $\begin{array}{l}\text { Giving voice } \\
\text { to the students } \\
\text { Compiling } \\
\text { students } \\
\text { initiatives }\end{array}$ & $\begin{array}{l}\text { Completion of a } \\
\text { survey on aspects } \\
\text { related to student } \\
\text { participation in } \\
\text { the classroom and } \\
\text { centre. } \\
\text { Preparation of } \\
\text { proposals for } \\
\text { improving school } \\
\text { Organization of } \\
\text { an assembly to } \\
\text { disseminate the } \\
\text { results of the } \\
\text { survey }\end{array}$ \\
\hline $\begin{array}{l}\text { Design, } \\
\text { development } \\
\text { and } \\
\text { evaluation of } \\
\text { the plan }\end{array}$ & $\begin{array}{l}\text { Designing the } \\
\text { improvement } \\
\text { plan } \\
\text { Evaluating the } \\
\text { plan }\end{array}$ & $\begin{array}{l}\text { Execution of the } \\
\text { plan } \\
\text { Evaluation of the } \\
\text { plan } \\
\text { Evaluation of the } \\
\text { project }\end{array}$ \\
\hline
\end{tabular}

\subsection{First contact with the centre and}

\section{setting the first activities in motion}

\subsubsection{Choice of and arrival at the centre (1st stage)}

As the first stage of the Project, the members of the UC team decided to look for educational centres in the whole region, and of all education levels, who might be interested in participating, starting from the premise of the leading role to be played by the centres in setting these activities in motion. We set off from the idea that it should be the education community itself that should identify its difficulties and opportunities when seeking these proposals.
The strategy designed by the team began with the first contact with the management teams of centres, who once aware of the project, took on the task of finding those persons, i.e, tutors from the education levels in which they had decided to work, who would be most suitable for the project. In our case, after the appropriate meeting with the head teacher, it was the tutor from the 3rd Year who was chosen to form part of the research team. The continued involvement in other projects carried out in the centre, or the awareness of its functioning, having formed part of the previous management, were factors considered at the time of choosing. Another necessary condition for collaboration was the future sustainability of a project that would be fruitful for the centre and which would improve certain aspects thereof.

Carrying out a project focussed on student voice in our country counts on a previous requisite: making the community aware of what this education practice entails and the results that it hopes to obtain. As is well-known [2], be it in other contexts (for example, The United Kingdom, Canada or Australia), the implantation of this model has more than a decade of history, whereas in Spain there have been very few experiences carried out, and less even in the literature on this topic. Thus, the first steps of our collaboration were centred on explaining to the management of the centre, to the tutor, and to the group of pupils what the philosophy implied: on the one hand, listening to everything the students had to say about the education they received; and on the other hand, recognizing their contributions in the development of processes of improving school linked to their own training; finally, helping them to find (and get used to) new forms of participation that up to this moment had not formed part of their school life [9; 10].

\subsubsection{Knowing the dynamics of work and participation (2nd stage)}

The second of the stages named "identifying needs" represented the major step for the work to be carried out. To do this we carried out in-depth interviews with the tutor and the head teacher as well as various (non-participative) observation sessions in the classroom.

The interviews carried out on the tutor helped discover the working and participation dynamics of the students as well as different conceptions and valuations held on the pupils in general and on their possibilities of participation in particular. In the head teacher's case, this allowed us to obtain a general perspective of what happened in the centre: sources of possible participation, the offer of activities for students, families, and so on. 
The observation sessions were carried out in classes of differing kinds: on the one hand, the tutorial class, in which the whole group participated; and on the other hand, History, of which the diversification pupils did not form part. These observations helped us learn how the tutor worked with the group, the rules established when it came down to participating, the classroom atmosphere, students' behaviour and so on.

The interviews were transcribed and returned to the protagonists, who could, if they felt necessary, make any opportune corrections. In the case of the observations, the notes made by the researcher were set down in a table and then summarized.

It is worth pointing out that all information obtained at this stage (along with that belonging to previous or later sequences) was made available to the whole University research team via an online folder accessible to all researchers involved to allow them to add contributions and suggestions.

\subsubsection{Dialogue and awareness (3rd stage)}

Based on the compiled information, various meetings were held with the tutor, during which the main results obtained were put forward both in the interviews as well as in the observation sessions.

This way, as a direct result of the data analysis, four topics or vectors were designed to act as a link for the new meetings: pupil relations with the management and education community; participation in the classroom; participation dynamics, rules and routines; student participation in the school syllabus; work with families and their influence on pupils.

These new conversations with the tutor developed into a moment of negotiation and searching for consensus when it came to planning the most suitable activity to provide student voice, although, this was always done reinforcing their main role at the time of setting the characteristics of the activity to be carried out. In this sense, their opinion was vital when it came to deciding what and how to ask, when to run the activity, who should lead it, and so forth.

\subsection{Work with students}

\subsubsection{Giving student voice (4th stage)}

After a first assessment of the work possibilities with students, it was agreed to set up an activity structured in two parts: firstly, a closer understanding of the pupil's opinions through a survey, and secondly, the celebration of an assembly to disseminate the results.
The survey was carried out in pairs during the tutorial class and allowed us to find out their opinion on their possibilities of participation in the centre and classroom, about aspects on which they liked to give their opinion and participate in and on things they felt could be improved in the centre. Once their answers had been compiled and analysed by the tutor and researchers, they were made known in an assembly in which the whole class participated. In the second stage, the pupils were able to explain in more details the answers they had given in the survey, and this was when the first ideas appeared about what things should be changed in the school. Once we had become aware of these demands, the group was asked to make the rest of the centre know, taking their opinions beyond the classroom walls. At that moment we had not yet decided upon the target public for their opinions, although they were sure that the management team was the main target. Once the pupils had overcome their reticence and doubts about what the project meant, their level of interest increased and their degree of involvement in the project made them start to think, to draw up petitions and, above all, to justify such petitions, an exercise that, as they told us all this time, they had carried out on very few previous occasions.

During the development of the sessions that we dedicated to creating a list of proposals for improving the centre, our intention to involve other groups of pupils from the centre increased. News about the project spread around the centre like wildfire: not only did the group involved in the project think about what could be changed, they also sought to involve others in their undertaking. Thus, some students placed a document in the classrooms of all the Secondary Years, inviting their fellow pupils to sign in the case of a solid petition.

The activity that aroused most interest in the centre was the celebration of the assembly where the students showed their classmates, teachers and the centre management team their petitions and proposals for improvements in the centre. These proposals were geared towards material aspects such as the construction of a bicycle park, repairing the bathrooms and the athletics track, the creation of a wifi zone or the installation of vending machine for drinks and snacks. Apart from these, they asked for other possibilities such as the use of mobile phones during break-times and leaving the school premises at the same time (to be able to go to nearby shops to buy refreshments). During this session, to which all secondary pupils were invited, the petitions of the students were shown on Powerpoint presentations. After the presentation of the groups, there was a round of questions for the head teacher, who asked in turn as part of the bargain for considering their 
demands, commitment on the part of the students. We believe it is necessary to mention the atmosphere in which the session was run and the enthusiasm and hugh participation of the pupils. As one confessed to us in the meetings that we held after this activity to evaluate the work, "we never thought we would get so far ".

This request for commitment did not fall on deaf ears, and the following school year the tutor asked for the petitions to be put down in writing. The class delegate and sub-delegate were responsible for this, as well as getting the opinion of their group, grouped in pairs to make their ideas known, and then presented to the centre management.

The work that we have carried out throughout these years has been made public in the centre through various means: on the one hand, the group wrote an article for the school newspaper, "Candil”, in which they described the work carried out during the year, in order to make the whole education community aware of their work. Furthermore, the work was presented to the teachers by the tutor involved in the project with the purpose of not only spreading awareness of the work, but also that of giving other teachers the possibility of participation others who might be interested in this form of working in and understanding the school. We believe that dissemination of the work is fundamental for the recognition and acceptance of practices such as these.

\subsection{A reflection as to the work carried out}

\subsubsection{What have we achieved? (5th stage)}

The last of the stages of the project collates the moment in which not only did we evaluate the plan carried out by the pupils, tutor and researchers, but also the project as a whole with the aim to put it into practise with new lines of work after its completion [3]. Apart from the voices of the three agents involved in the work, we have been able to draw a "map" of strengths and weaknesses of our work. As we have explained elsewhere [7], based on the comments of the tutor (collected in an in-depth interview), of the students (via a questionnaire of open questions given out to the pupil and then later disseminated in an assembly) and of the researchers (who compiled a report of everything carried out in these years of work), we structured the information in terms of three vectors which allowed us to show the strengths and weaknesses of the project, as well as future development that would take place in the centre.
There were three vectors or lines chosen, not limiting analysis of other aspects of the project. The first, "the influence of the project on the group", directly related to the main actors in the project, that is to say the pupils; the second was linked with the "usefulness of the work carried" i.e. in terms of what we have learnt, and what our work has been for; and the third, which responds to one of the key demands of our plan, seeking to know the "satisfaction of the demands carried out" and in terms of aspects linked to the scope of the project, its use in the future.

With regard to the first of these vectors, we feel that the main effect of our work has been the change in self-confidence and self-perception of the group. They have realized what their voice can actually do, a power that can be used not only in their training as pupils, but rather in a much more complex area, as citizens in a democratic society. In this point, we would like to stress how the opportunity of offering a new way of working to the group has helped it to understand that they have a voice, or at least they can have one, and that they have the capacity to give their opinions and speaking. Furthermore, as witness to the work carried out by their students, the tutor has completely changed the vision that the pupils had previously had (centred on many occasions on negative aspects liked with passivity, lack of interest, and so on), a situation that has made it possible to build a new framework of relationships and has created new areas of dialogue that have enriched ad improved the work between both parties.

The "usefulness of the work carried out" can well be demonstrated from some of the activities carried out from the outset of the project. The mere consultation with the pupils, the opportunity to give them voice to say what they like and dislike about the school can be considered to be a change in the school culture of this centre, and hence an objective fulfilled, by sparking an improvement in the centre geared to creating a school that is more democratic and consequently more inclusive [5].

Apart from the effects on the group, the project has also had an effect on the tutor and on the researchers themselves. For the tutor it has meant a new perspective of the group, that in a profound way, involves a change in the conception that childhood and youth has determined teaching practices, stuck in the consideration that these ages are a nonresponsible, non-competent or immature group, which has then crystallized over time into the assignation of a status of inferiority and incapacity [13] and lest we forget, has conditioned the forms of relationships, the assignation of responsibilities or the conception of their role in society. Moreover, the project has represented for us, the researchers, the opportunity to carry out "collaborative research", 
working as co-researchers with professionals from teaching centres in search of improving schools. In this sense, we set off from the idea that the research team is really a facilitator, a gearstick that motivates this new form of working but which must leave in the hands of each school, and the persons involved the control of the project as one more activity in the centre, and even a sign of the centre's identity.

Lastly, the "satisfaction of the demands" appears in the three actors' comments as the cornerstone to the project's complete success. At the time of writing some of the demands requested by the pupils are being revised, and we hope that in coming years they will be put into action. We are aware that the setting up of a project of this nature implies a new way of working which in turn involves a rethink of the hierarchical pupil-teacher relationships $[11 ; 12]$ and a reflection as to not just teaching practice, but also the management of education centres, although we defend the idea that the promotion of this way of understanding education, generating open, democratic and dialogue-oriented schools in which the reflection on questions that concern, and occupy thoughts, in the school scenario, may be transformed into practices to which the whole of the education community is invited, with the same voice, at the same level and with the same repercussion.

\section{Final note}

After these years of collaboration and mutual learning among the researchers, the centre, the group of pupils and the tutor, we would like to value and support the setting up of such works which as their ultimate objective, seek to improve school and put on the same level all the actors who make up the education community.

Our work has allowed us to endorse the idea of the importance of creating measures for giving voice to those groups who, for one reason or other, have been left out in the cold in school and which has allowed us to visualize the capacity of teenagers to carry out work like this with the rigour required. It is only through getting rid of adult-oriented visions [2] as to childhood and youth will we be in a position to start a new way of understanding school in which pupils are not only considered as receivers but also as the spokespersons for all decisions taken in the school.

We believe that an activity such as the one we have narrated, just like those carried out at other education levels in the framework of the same project $[5 ; 6]$, has opened a window that should not be closed in our attempts to find a school is more inclusive by the day. In this sense, we feel are convinced that is vital to analyse, negotiate and agree upon the setting up of some (if not all) of the demands requested by pupils in order to value the usefulness and ultimate objective of the project. We set off from the idea that giving voice to pupils implies, in an inexcusable fashion, listening to the voice of the group, that is to say, we believe that giving voice to pupils, and to whatever group, needs an ulterior action: listening to their words, that is, counting on spokespersons that not only exercise their right to talk, to give their opinion, but furthermore being capable of answering their demands and incorporating them into the life of centres. All this can be considered as "blowing in the wind" if this condition is not met.

\section{4. $\quad$ References}

[1] Ainscow, Mel, Desarrollo de escuelas inclusivas., Narcea, Madrid, 2001.

[2] Susinos, Teresa, "Escuchar para compartir. Reconociendo la autoridad del alumnado en el proyecto de una escuela inclusiva”, Revista de Educación, N ${ }^{\circ} 349$, 2009, pp. 119-136.

[3] Susinos, Teresa and Rodríguez Hoyos, Carlos, "La educación inclusiva hoy. Reconocer al otro y crear comunidad a través del diálogo y la participación”, Revista Interuniversitaria de Formación del Profesorado, 70 (25, 1), 2011, pp. 15- 30.

[4] Messiou, Kiki, Confronting marginalisation in education: A framework for promoting inclusion, Routledge, London, 2012.

[5] Calvo, Adelina; Rodríguez- Hoyos, Carlos and García Lastra, Marta, "Lo mejor de todo es que nos escucháis". Investigar el aumento de la participación de los estudiantes en los Programas de Diversificación y de Cualificación Profesional Inicial”, Revista de Educación, 359, 2012, pp. 164- 183.

[6] Rojas Pernia, Susana; Haya Salmón, Ignacio y LázaroVisa, Susana, "La voz del alumnado en la mejora escolar: niños y niñas como investigadores en Educación Primaria”, Revista de Educación, 359, 2012, pp. 81-101.

[7] García Lastra, Marta and Susinos Rada, Teresa, "Reflexiones para seguir avanzando: un proyecto de mejora de la escuela a través de la voz del alumnado", Actas de la XVI Conferencia de Sociología de la Educación (in press).

[8] Ainscow, Mel, Understanding the development of inclusive school, Routdlegde Folner, Oxon, 1999.

[9] Rudduck, Jean and Flutter, Julia, Cómo mejorar tu centro escolar dando la voz al alumnado, Morata, Madrid, 2007. 
[10] Escudero, Juan Manuel and García, Rodrigo J., "Prólogo", Asociación Escuela y Autogestión, Tomemos la palabra. La voz del alumnado de Educación Secundaria en Puente de Vallecas, pp. 11-24. Madrid: Editorial Popular, 2009.

[11] Fielding, Michael and Bragg, Sara, Students as researchers. Making a difference. Cambridge. Pearson Publications, 2003.

[12] Fielding, Michael, "Transformative approaches to student voice: theoretical underpinnings, recalcitrant realities”, British Educational Research Journal, Vol. 30, 2, 2004, pp. 295-311.

[13] Álvarez- Uría, Fernando and Varela, Julia, Sociología de las instituciones. Bases sociales y culturales de la conducta, Morata, Madrid, 2009. 